\title{
Animal cloning by nuclear transfer: state-of-the-art and future perspectives ${ }^{\star}$
}

\author{
Andras Dinnyes ${ }^{1,2 \varpi}$ and Agnes Szmolenszky ${ }^{1}$ \\ ${ }^{1}$ Department of Animal Biology, Agricultural Biotechnology Center, Gödöllö, Hungary; ${ }^{2}$ Research Group on \\ Applied Animal Genetics and Biotechnology, Szent Istvan University and Hungarian Academy of Sciences,

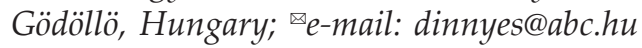

Received: 15 March, 2005; revised: 03 August, 2005; accepted: 05 August, 2005 available on-line: 15 September, 2005

\begin{abstract}
Model organisms are essential to study the genetic basis of human diseases. Transgenic mammalian models, especially genetic knock-out mice have catalysed the progress in this area. To continue the advancement, further sophisticated and refined models are crucially needed to study the genetic basis and manifestations of numerous human diseases. Coinciding with the start of the new era of post-genomic research, new tools for establishment of transgenesis, such as nuclear transfer and gene targeting in somatic cells, have become available, offering a unique opportunity for the generation of transgenic animal models. The new technology provides important tools for comparative functional genomics to promote the interpretation and increase the practical value of the data generated in numerous mouse models. This paper discusses the state-of-the-art of the nuclear replacement technology and presents future perspectives.
\end{abstract}

Keywords: cloning, transgenic, animal models, epigenetics

Transgenic animal models have played and are anticipated to continue to play an important role in our pursuit of knowledge of the genetic basis of human disease. There is a need for animal models instead of cell culture because of the complexity of the biological processes that form the basis of most diseases. To-date, most of the available information has been generated in the mouse. The availability of stable embryonic stem cell lines enables gene targeting technology in the mouse. However, the lack of such cell lines in most mammals has so far prevented targeted genetic modifications. Although murine models have been of great use, the potential of the mouse model is limited because the anatomy and physiology of the mouse is not always fully adequate to study many of the diseases affecting the human population. Many species have metabolism and organs with characteristics much closer to that of humans than is the case in mouse (such as lipoprotein metabolism and the development of atherosclerosis in rabbits, skin structure and organ capacity and size for transplantation in pig). However, the lack of stable stem cell lines in animal species other than the mouse has blocked the way for the usage of refined genetic tools for specific targeted genetic models. Furthermore, the difficulties and expenses of the conventional method for generating transgenic models has hindered the progress. The nuclear transfer technology has become available for studies in non-murine species and can be exploited to bridge the gap between mouse models and treatment of human diseases by generating transgenic models in other species.

Despite its great potentials, the nuclear transfer technology is still in its infancy. Some of the reasons for the low efficiency and the possibilities to overcome the present limitations are described below.

\section{STATE OF NUCLEAR TRANSFER}

Since the first mammals to be 'cloned' from cultured differentiated cells (Campbell et al., 1996), and the birth of 'Dolly', the first mammal derived from an adult somatic cell (Wilmut et al., 1997) progress was fast. Milestones included the first transgenic mammal to be produced by nuclear

^Presented at the International Review Conference on Biotechnology, Vienna, Austria, November 2004. 
transfer from a cell line genetically modified in culture (Schnieke et al., 1997); the first nuclear transfer pigs (Polejaeva et al., 2000; Onishi et al., 2000) and the first gene-targeted non-murine mammals (McCreath et al., 2000, first "knock-in" lambs; Denning et al., 2001a, first "knock-out" lamb; Phelps et al., 2003, first knock-out pig). Nuclear replacement efficiency varies among species. In cattle the reported percentage of born progeny increased from the initial 1\% to around $20 \%$. This considerable progress is due, besides the improved nuclear replacement methods, to better embryo culture systems. The mouse nuclear transfer technology is relatively well established (Wakayama et al., 1999; Zhou et al., 2001). In rabbit, development of the technology recently resulted in the first somatic-cell nuclear transfer rabbit (Chesne et al., 2002). The technology has also resulted in live birth in other mammals, including rat (Zhou et al., 2003), goat (Baguisi et al., 1999), horse (Galli et al., 2003), mule (Woods et al., 2003), cat (Shin et al., 2002), banteng, gaur (Lanza et al., 2000), African Wildcat (Gomez et al., 2004) and dog (Lee et al., 2005). In human, nuclear transfer embryos have been created, and embryonic stem cell lines established from them for potential cell therapy ("therapeutic cloning", Hwang et al., 2004; 2005).

These successes do, however, mask several confounding issues, including the limited lifespan of primary somatic cells in culture as well as the low efficiency of gene targeting in these cells (Denning et al., 2001b), which effectively limits the target genes to those that are expressed in the donor cell. Complex strategies need to be developed to overcome such restraints.

\section{CRITICAL ASPECTS OF NUCLEAR TRANSFER}

Somatic cell nuclear transfer is characterised by a series of developmental abnormalities, the so called cloning-syndrome. This encompasses higher rates of pregnancy loss, prolonged gestation, higher birth weight, higher rates of peri- and post-natal mortality and specific adult phenotypes (Hill et al., 1999; De Sousa et al., 2001). Only about two-thirds of clones delivered at term survive at least until weaning. It has been claimed that at least these long-term survivors can be physiologically normal and apparently healthy, displaying normal behaviour, growth rates, reproduction and productivity. Equally, there are reports of various abnormal cloning-associated phenotypes, including higher annual mortality rates in cattle, reduced maximal lifespan, and obesity in mice (Eggan et al., 2001; Tamashiro et al., 2002), and compromised immune function in both species (Renard et al., 2002). The incidence of these anomalies varies according to the species, genotype, donor cell status, or specific aspects of the nuclear transfer and culture protocols used and it is not clear which of them could be eliminated by technical improvements. Despite the present inefficiencies, mouse nuclear replacement experiments have proven that this method is already capable of improving the efficiency of transgenic production compared to traditional methods (Wakayama et al., 2001).

\section{NUCLEAR REPROGRAMMING AND EPIGENETICS}

The reasons behind the frequent deformations and high mortality among nuclear replacement foetuses and progeny are not well understood, but genetic reprogramming problems are likely to be involved. In natural reproduction, relatively low levels of DNA methylation exist in the male and female gametes, which are further demethylated during early embryo development. With nuclear transplantation, the somatic nucleus carries the specific epigenetic modifications of its tissue type, which must be erased during nuclear reprogramming. Therefore, the levels of epigenetic modification existing in donor cells may affect their reprogrammability following nuclear transfer. A discrepancy in the reprogrammability has been observed in different cell types, which results in altered in vitro and in vivo development of cloned embryos (Kato et al., 2000; Rideout et al., 2000).

Nuclear transfer embryos are known for problems of implantation, abnormalities in placental development and losses during pregnancy. These aberrations are consequences of epigenetic errors, and studies on the frequency of such errors in various genes have revealed that imprinted genes, very important for placental development, are particularly often affected (Rideout et al., 2001). According to recent data, these epigenetic deviations are reset in the second generation after nuclear replacement in conjunction with gametogenesis (Tamashiro et al., 2002). It is, however, an absolute requirement that the first generation of nuclear replacement animals is epigenetically normal enough to complete embryogenesis, foetal development and adaptation to post-natal life.

Mitochondrial inheritance is a specific issue in nuclear replacement and deserves special attention during the development of the technology. However, it is now evident that the offspring generated through nuclear replacement has inconsistent patterns of mtDNA inheritance, often with mixed populations (heteroplasmy) of mtDNA (Takeda et al., 1999; Hiendleder et al., 2003; Steinborn et al., 2000). This heteroplasmy can arise from the introduction of mtDNA accompanying the donor nucleus into the reconstructed embryo and/or the use of recipient oocytes from the ovaries of different females. 'Dolly the lamb' possessed only the recipient egg mtDNA 
(Evans et al., 1999). However, in each case, the nuclear donor will remain the same and analysis of nuclear DNA alone will indicate that these offspring are identical.

\section{ADDITIONAL FACTORS AFFECTING NUCLEAR TRANSFER EFFICIENCY}

The efficiency of nuclear replacement is also influenced by the donor cells, in vitro activation and cultivation methods and technical aspects regarding micromanipulation. The origin of the donor cells affects success rates and survival in culture. For any given somatic cell type, the best source for nuclear transfer is still a matter of debate. The highest cloning efficiencies were achieved with oocytes and donor cells of hybrid mice.

\section{FUTURE PERSPECTIVE}

Nuclear transfer is a fast developing technique, far from being optimized. Evolution in the efficiency and applicability in new species is expected. However, it is not clear how much of an improvement can be achieved by simply optimizing the present protocols. Revolutionary changes in our understanding of the reprogramming of the nuclear material, organization of chromatin and epigenetic changes are necessary to allow proper control of the procedures and to avoid epigenetic aberrations in the progeny. Clones of the same donor provide unique experimental material since they are genetically identical yet may be epigenetically different regarding imprinted and X-linked genes. Therefore, the nuclear transfer animal model provides insight into epigenetic regulation that cannot be studied in natural reproduction.

Several new technologies and molecular biological events are studied preferentially in mice, but the practical production of transgenic animals in this species is not likely to be dominated by the nuclear transfer procedures in the near future, as the existing microinjection and embryonic stem cell technology-based methods work efficiently. However, comparison of embryonic stem- and somatic-cell nuclear transfer in mouse will allow a true validation of the nuclear transfer technology for standardized transgenic animal production.

Rat nuclear transfer is one of the biggest technological challenges, partially due to the high sensitivity of rat oocytes to spontaneous parthenogenetic activation. Recently, rat nuclear transfer succeeded as well, using chemicals that block pre-activation before nuclear transfer (Zhou et al., 2003). Use of transgenic rats in the pharmaceutical testing of new drugs might be one of the main activities in the fu- ture, and nuclear transfer might represent a viable method to produce stable knock-out and knock-in animals in this important species.

Rabbit nuclear transfer has been successful in producing progeny with fresh cumulus cells, but not with cultured cells. Several transgenic human disease models could be developed in rabbit which are not available in mouse, due to anatomical and physiological differences (e.g., cystic fibrosis, atherosclerosis). Furthermore, placenta structure of the rabbit resembles that of the human, providing a chance for model studies on human reproduction.

Basic research in nuclear reprogramming will continue, especially due to connections to the embryonic stem cell research field. Practical application of nuclear transfer in the near future is expected in the agriculture for enhanced food production and propagation of superior breeding stock; in medicine by using animals as novel disease models, bioreactors and organ donors produced by the combination of transgenesis/homologous recombination in somatic cell lines and nuclear transfer; and in therapeutic cloning of human embryos. Methods with much improved efficiency would provide a good tool for endangered species preservation efforts, as well. In the case of industrial utilization the importance of avoiding inbreeding with advanced breeding management will increase.

\section{Acknowledgements}

This research was supported by grants of OTKA T046171, Bilateral Scientific and Technological Collaborations (TET, No. A10/02, No. GB52/01) between Austria, UK and Hungary and the Hungarian National Office of Research and Technology (OM-KMUFA; Bio-00017/2002).

\section{REFERENCES}

Baguisi A, Behboodi E, Melican DT, Pollock JS, Destrempes MM, Cammuso C, Williams JL, Nims SD, Porter CA, Midura P, Palacios MJ, Ayres SL, Denniston RS, Hayes ML, Ziomek CA, Meade HM, Godke RA, Gavin WG, Overstrom EW, Echelard Y (1999) Production of goats by somatic cell nuclear transfer. Nat Biotechnol 17: 456-461.

Campbell KH, McWhir J, Ritchie WA, Wilmut I (1996) Sheep cloned by nuclear transfer from a cultured cell line. Nature 380: 64-66.

Chesne P, Adenot PG, Viglietta C, Baratte M, Boulanger L, Renard JP (2002) Cloned rabbits produced by nuclear transfer from adult somatic cells. Nat Biotechnol 20: 366-369.

Denning C, Burl S, Ainslie A, Bracken J, Dinnyes A, Fletcher J, King T, Ritchie M, Ritchie WA, Rollo M, de Sousa P, Travers A, Wilmut I, Clark AJ (2001a) Deletion of the $\alpha(1,3)$ galactosyl transferase (GGTA1) gene and the prion protein $\operatorname{PrP}$ ) gene in sheep. Nat Biotechnol 19: 559-562. 
Denning C, Dickinson P, Burl S, Wylie D, Fletcher J, Clark AJ (2001b) Gene targeting in primary fetal fibroblasts from sheep and pig. Cloning Stem Cells 3: 221-231.

De Sousa PA, King T, Harkness L, Young LE, Walker SK, Wilmut I (2001) Evaluation of gestational deficiencies in cloned sheep fetuses and placentae. Biol Reprod 65: 23-30.

Eggan K, Akutsu H, Loring J, Jackson-Grusby L, Klemm M, Rideout WM 3rd, Yanagimachi R, Jaenisch R (2001) Hybrid vigor, fetal overgrowth, and viability of mice derived by nuclear cloning and tetraploid embryo complementation. Proc Natl Acad Sci USA 98: 6209-6214.

Evans MJ, Gurer C, Loike JD, Wilmut I, Schnieke AE, Schon EA (1999) Mitochondrial DNA genotypes in nuclear transfer-derived cloned sheep. Nat Genet 23: 90-93.

Galli C, Lagutina I, Crotti G, Colleoni S, Turini P, Ponderato N, Duchi R, Lazzari G (2003) A cloned horse born to its dam twin. Nature 424: 635.

Gomez MC, Pope CE, Giraldo A, Lyons LA, Harris RF, King AL, Cole A, Godke RA, Dresser BL (2004) Birth of African Wildcat cloned kittens born from domestic cats. Cloning Stem Cells 6: 247-258.

Hiendleder S, Zakhartchenko V, Wenigerkind H, Reichenbach HD, Bruggerhoff K, Prelle K, Brem G, Stojkovic M, Wolf E (2003) Heteroplasmy in bovine fetuses produced by intra- and inter-subspecific somatic cell nuclear transfer: neutral segregation of nuclear donor mitochondrial DNA in various tissues and evidence for recipient cow mitochondria in fetal blood. Biol Reprod 68: 159-166.

Hill JR, Roussel AJ, Cibelli JB, Edwards JF, Hooper NL, Miller MW, Thompson JA, Looney CR, Westhusin ME, Robl JM, Stice SL (1999) Clinical and pathologic features of cloned transgenic calves and fetuses (13 case studies). Theriogenology 51: 1451-1465.

Hwang WS, Ryu YJ, Park JH, Park ES, Lee EG, Koo JM, Jeon HY, Lee BC, Kang SK, Kim SJ, Ahn C, Hwang JH, Park KY, Cibelli JB, Moon SY (2004) Evidence of a pluripotent human embryonic stem cell line derived from a cloned blastocyst. Science 303: 1669-1674.

Hwang WS, Roh SI, Lee BC, Kang SK, Kwon DK, Kim S, Kim SJ, Park SW, Kwon HS, Lee CK, Lee JB, Kim JM, Ahn C, Paek SH, Chang SS, Koo JJ, Yoon HS, Hwang JH, Hwang YY, Park YS, Oh SK, Kim HS, Park JH, Moon SY, Schatten G (2005) Patient-specific embryonic stem cells derived from human SCNT blastocysts. Science 308: 1777-1783.

Kato Y, Tani T, Tsunoda Y (2000) Cloning of calves from various somatic cell types of male and female adult newborn and fetal cows. J Reprod Fertil 120: 231-237.

Lanza RP, Cibelli JB, Diaz FM, Farin PW, Farin CE, Hammer CJ, West MD, Damiani P (2000) Cloning of an endangered species (Bos gaurus) using interspecies nuclear transfer. Cloning 2: 79-91.

Lee BC, Kim MK, Jang G, Oh HJ, Yuda F, Kim HJ, Shamim MH, Kim JJ, Kang SK, Schatten G, Hwang WS (2005) Dogs cloned from adult somatic cells. Nature 436: 641.

McCreath KJ, Howcroft J, Campbell KH, Colman A Schnieke AE, Kind AJ (2000) Production of gene-targeted sheep by nuclear transfer from cultured somatic cells. Nature 405: 1066-1069.

Onishi A, Iwamoto M, Akita T, Mikawa S, Takeda K, Awata T, Hanada H, Perry AC (2000) Pig cloning by microinjection of fetal fibroblast nuclei. Science 289: 1188-1190.
Phelps CI, Koike C, Vaught TD, Boone J, Wells KD, Chen SH, Ball S, Specht SM, Polejaeva IA, Monahan JA, Jobst PM, Sharma SB, Lamborn AE, Garst AS, Moore M, Demetris AJ, Rudert WA, Bottino R, Bertera S, Trucco M, Starzl TE, Dai Y, Ayares DL (2003) Production of alpha 1,3-galactosyltransferase-deficient pigs. Science 299: 411-414.

Polejaeva IA, Chen SH, Vaught TD, Page RL, Mullins J, Ball S, Dai Y, Boone J, Walker S, Ayares DL, Colman A, Campbell KH (2000) Cloned pigs produced by nuclear transfer from adult somatic cells. Nature 407: 86-90.

Renard JP, Zhou Q, LeBourhis D, Chavatte-Palmer P, Hue I, Heyman Y, Vignon X (2002) Nuclear transfer technologies: between successes and doubts. Theriogenology 5:, 203-222.

Rideout WM 3rd, Wakayama T, Wutz A, Eggan K, Jackson-Grusby L, Dausman J, Yanagimachi R, Jaenisch R (2000) Generation of mice from wild-type and targeted ES cells by nuclear cloning. Nat Genet 24: 109-110.

Rideout WM 3rd, Eggan K, Jaenisch R (2001) Nuclear cloning and epigenetic reprogramming of the genom, Science 293: 1093-1098.

Schnieke AE, Kind AJ, Ritchie WA, Mycock K, Scott AR, Ritchie M, Wilmut I, Colman A, Campbell KH (1997) Human factor IX transgenic sheep produced by transfer of nuclei from transfected fetal fibroblasts. Science 278: 2130-2133.

Shin T, Kraemer D, Pryor J, Liu L, Rugila J, Howe L, Buck S, Murphy K, Lyons L, Westhusin M (2002) A cat cloned by nuclear transplantation. Nature 415: 859.

Steinborn R, Schinogl P, Zakhartchenko V, Achmann R, Schernthaner W, Stojkovic M, Wolf E, Muller M, Brem G (2000) Mitochondrial DNA heteroplasmy in cloned cattle produced by fetal and adult cell cloning. Nat Genet 25: 255-257.

Takeda K, Takahashi S, Onishi A, Goto Y, Miyazawa A, Imai H (1999) Dominant distribution of mitochondrial DNA from recipient oocytes in bovine embryos and offspring after nuclear transfer. J Reprod Fertil 116: 253259.

Tamashiro KL, Wakayama T, Akutsu H, Yamazaki Y, Lachey JL, Wortman MD, Seeley RJ, D'Alessio DA, Woods SC, Yanagimachi R, Sakai RR (2002) Cloned mice have an obese phenotype not transmitted to their offspring. Nat Med 8: 262-267.

Wakayama T, Yanagimachi R (1999) Cloning of male mice from adult tail-tip cells. Nat Genet 22: 127-128.

Wakayama T, Tabar V, Rodriguez I, Perry AC, Studer L, Mombaerts P (2001) Differentiation of embryonic stem cell lines generated from adult somatic cells by nuclear transfer. Science 292: 740-743.

Wilmut I, Schnieke AE, McWhir J, Kind AJ, Campbell KH (1997) Viable offspring derived from fetal and adult mammalian cells. Nature 385: 810-813.

Woods GL, White KL, Vanderwall DK, Li GP, Aston KI, Bunch TD, Meerdo LN, Pate BJ (2003) A mule cloned from fetal cells by nuclear transfer. Science 301: 1063.

Zhou Q, Jouneau A, Brochard V, Adenot P, Renard JP (2001) Developmental potential of mouse embryos reconstructed from metaphase embryonic stem cell nuclei. Biol Reprod 65: 412-419.

Zhou Q, Renard JP, Le Friec G, Brochard V, Beaujean N, Cherifi Y, Fraichard A, Cozzi J (2003) Generation of fertile cloned rats by regulating oocyte activation. Science 302: 1179 . 